\title{
Cross-cultural adaptation and validation of the VISA-A questionnaire for German-speaking Achilles tendinopathy patients
}

Heinz Lohrer ${ }^{*}$, Tanja Nauck ${ }^{\dagger}$

\section{Correction}

After the work [1] was published in provisional form we realized a major error with regard to contents.

On page 4, in the first paragraph of the second column, the third sentence scores collected using different grading systems were compared. The difference "comparing the preoperative with the conservative patients, the students, and the joggers group respectively" was $\mathrm{p}=0.000$ for each individual comparison. Therefore in line eight and nine the term "...did not differ..." inverts this context. That phrase therefore has to be corrected to: “...differed significantly..."

The authors regret any inconvenience potentially caused by this error.

Received: 26 February 2010

Accepted: 26 February 2010 Published: 26 February 2010

\section{References}

1. Lohrer H, Nauck T: Cross-cultural adaptation and validation of the VISA-A questionnaire for German-speaking Achilles tendinopathy patients. BMC Musculoskelet Disord 2009, 10:134

\section{Pre-publication history}

The pre-publication history for this paper can be accessed here:http://www biomedcentral.com/1471-2474/11/37/prepub

\section{doi:10.1186/1471-2474-11-37}

Cite this article as: Lohrer and Nauck: Cross-cultural adaptation and validation of the VISA-A questionnaire for German-speaking Achilles tendinopathy patients. BMC Musculoskeletal Disorders 2010 11:37.

\footnotetext{
* Correspondence: lohrer@smi-frankfurt.de

† Contributed equally

Institute for Sports Medicine, Otto-Fleck-Schneise 10, D-60528 Frankfurt am Main; Germany
}

(c) 2010 Lohrer and Nauck; licensee BioMed Central Ltd. This is an Open Access article distributed under the terms of the Creative

Submit your next manuscript to BioMed Central and take full advantage of:

- Convenient online submission

- Thorough peer review

- No space constraints or color figure charges

- Immediate publication on acceptance

- Inclusion in PubMed, CAS, Scopus and Google Scholar

- Research which is freely available for redistribution

Submit your manuscript at 